This is an Accepted Manuscript of an article published by Taylor \& Francis in Changing English on 11/12/18, available online:

https:/www.tandfonline.com/doi/full/10.1080/1358684X.2018.1545109. 


\section{Title page}

Exploratory talk and task based learning: a case study of a student's learning journey on an MA (Education) English language teaching course.

Valerie Coultas

Email:valerieharry@aol.com

Independent, UK

Paul Booth

Department of Humanities

Kingston University

Kingston upon Thames, UK

Email: p.booth@kingston.ac.uk 


\begin{abstract}
This article records and evaluates a student's learning journey in two modules on an MA (Education) English Language Teaching (ELT) programme: an Oracy and ELT pedagogy module and an Educational Technologies module. The notions of 'exploratory talk' and 'task based learning' are explored using a single case study with material drawn from the student's autobiography and diary, the spoken and written assignments and the student and lecturers' reflections on completion of the modules. We show, through the use of autobiography and critical reflection, what the student brings to the course and how this reflection allows him to use and transfer knowledge from one module to another. We analyse the ways in which the modules complement each other and how this influences the student's learning and teaching practice. We then identify the key features of his learning in relation to E LT pedagogy.
\end{abstract}

Keywords: exploratory talk, task based language teaching, narrative, Talk Autobiography, critical reflection, teacher education, ELT pedagogy, home literacy practices 


\title{
Exploratory talk and task based learning: a case study of a student's learning journey on an MA (Education) English language teaching course.
}

'learning does not always come from the 'top' but.... in a certain sense, is shared from the bottom' (Florence, 2014)

\begin{abstract}
This article records and evaluates a student's learning journey in two modules on an MA (Education) English Language Teaching (ELT) programme: an Oracy and ELT pedagogy module and an Educational Technologies module. The notions of 'exploratory talk' and 'task based learning' are explored using a single case study with material drawn from the student's autobiography and diary, the spoken and written assignments and the student and lecturers' reflections on completion of the modules. We show, through the use of autobiography and critical reflection, what the student brings to the course and how this reflection allows him to use and transfer knowledge from one module to another. We analyse the ways in which the modules complement each other and how this influences the student's learning and teaching practice. We then identify the key features of his learning in relation to E LT pedagogy.
\end{abstract}

Keywords: exploratory talk, task based language teaching, narrative, Talk Autobiography, critical reflection, teacher education, ELT pedagogy, home literacy practices

\section{Introduction, rationale and key terms}

The master's programme, an MA (Education) in English Language Teaching (ELT) at the School of Education at Kingston University (2013-2014), was a joint venture between the staff in the School of Education and the staff in the Linguistics and Languages Department of the School of Humanities. This article uses a case study approach to explore a student's learning journey on two modules of this MA programme, the Oracy and ELT Pedagogy module and the Educational Technologies module.

We were interested in finding out what prior knowledge and experience a new teacher brought to his learning, how knowledge and skills transferred from one module to another and what the experience of the two modules taught him about teaching English as a second language. The talk autobiography, building on the work of Britton (1970), Rosen (1996), and Miller (1995), reflecting on the role of talk in the student's own language learning, played a key role in allowing students to tell the story of their own language learning journeys and identify and reflect critically on their prior knowledge and educational experiences. Clandinin and Connelly (2000) also suggest that such personal narratives can promote reflection and alter practice. These understandings of their own experiences then informed the thinking and academic research of the students and the peer teaching tasks in both modules.

Some key concepts were central to the construction of these two modules. Oracy refers to the use of spoken communication and conversation as a route to language acquisition and as means of learning. Underpinning the Oracy and ELT Pedagogy module was the need for students to have an overall approach or philosophical stance towards language teaching. Central to the construction of the Oracy module was the philosophy of Vygotsky (1986), a 
psychologist with a social view of development in general and language in particular, who emphasised that as we interact with others and use words to solve problems we develop and clarify our thinking. Vygotsky was interested in finding better ways of organizing pedagogy that adapted to the learners' needs.

Central to our particular interpretation of a sociocultural approach were the ideas of teachers and writers in working around language and learning in multicultural contexts in London schools in the 70's and 80's when English teaching was experiencing an innovative period. In this context many English teachers were attempting to celebrate linguistic and cultural diversity in their classrooms (Coultas, 2015a, b). The Oracy and ELT Pedagogy module built on these ideas to explore the role of oracy in the English as an Additional Language (EAL) and English as a Second Language (ESL) classroom. The authors therefore fully subscribe to the idea that English is a multilingual subject. Brutt-Griffler and Collins (2007) also highlight how in English language classrooms English and other languages can be used together to construct meaning.

As teachers coming from slightly different English teaching traditions, we were also interested in widening our understanding of the concept of 'exploratory talk', a concept central to the first module and 'task-based learning', and a key idea in the later module.

Exploratory talk, in the native English teaching and EAL tradition, was a key concept in the Oracy and English Language Teaching module because meaning making and authenticity of the task are both vital through tentative and exploratory talk. The idea of exploratory talk, or as Barnes (1976) first coined it 'the classroom conversation', therefore focuses on the social construction of knowledge through students articulating their inner voices to each other in the security of the small group before moving to presentational talk to a larger group. Mercer's work on ground rules for group work has sought to identify the processes that make for effective exploratory talk (Mercer 2000, Mercer and Hodgkinson 2008). In an ESL and EAL context learning talk and classroom dialogue (Alexander, 2004, 2008; Barnes, 2008, Cordon, 2000, Coultas, 2012, Gibbons, 2009, Richmond 2015 and Wells, 1987) are central and the role of oral rehearsal and collaborative work is particularly vital (Scott, 2011).

Central to the construction of the Educational Technologies module was task-based teaching which was used as a language teaching approach. As with exploratory talk, learners are given tasks which are designed to foster language learning. Prabhu (1987) describes language tasks which are meaning based. Task-based teaching relies on a focus on learners' production of meaningful discourse, for example tasks such as opinion-gap activities designed for learners to identify and articulate a personal preference, feeling, attitude in response to a given situation. Learners are engaged in understanding others and expressing meaning in a second language which at a sub-conscious level drives second language development (Prabhu 1987, 69). It is important to note that comprehension alone is insufficient for second language development (Long 1996). Task-based activity not only involves comprehension but also gives learners the opportunity to continually focus on meaning which demands spontaneous and structurally dissimilar samples of language that have not been rehearsed. Therefore, 
despite different terminology, there were similarities in approaches to pedagogy from both the Oracy and Pedagogy module and the Educational Technologies module.

\section{The pedagogy of the Oracy Module}

Britton, as long ago as 1970, highlighted the central role of talk in language learning and in rehearsing and empowering writers when he suggested that 'all that children write...takes place upon a sea of talk' $(1970,29)$. Britton also understood that human beings have a basic need to symbolise their experience and that therefore we all had stories to tell about our lives and wanted to make sense of our own experiences. He therefore highlighted the role of expressive and personal talk and writing in the learning process (Coultas, 2018).

This module and the talk autobiography built on the work of Britton and those who insisted in the 80's 'on narrative in defence of other priorities' as this was 'at the very heart of the attempt to keep meaning at the centre of language education' (Rosen, 1985, 26). In utilising autobiographical narrative and this expressive mode the module also incorporated some of the intuitive practices of teachers in London schools serving diverse and multicultural communities who had encouraged children to write their own language autobiographies and build on their own language experiences in their talk and writing in the 1980s when the Inner London Education Authority (ILEA) was running state schools, (Eyers and Richmond, 1982, Eyers, 2015, Coultas 2009, 2015a, b, c). This personal and autobiographical approach had been particularly effective for London children newly arrived in England and also proved to be a powerful stimulus for the students on this MA course, many of whom came from overseas (Coultas, 2018).

The module had four key elements: the writing of a language autobiography to stimulate reflection on the role of spoken language in learning; a review of the relevant literature; modelling and rehearsal of key strategies for promoting oracy with a visit to a school to observe school based practice and, finally, planning and teaching a lesson with a partner that modelled a talk task that required not just invited talk (Gibbons, 2009).

\section{The Talk autobiography and the planning for talk}

The initial sessions of the Oracy and Pedagogy module focused on the discussion and writing of the language autobiography. Students were asked to write an autobiography to focus on the role that spoken language had played in the learning of both their native language and a second language.

The writing was stimulated in two ways: firstly, using an individual timeline, along which students could delineate their personal experiences of spoken language positively or negatively (see Appendix 1). This was used to explore from birth circumstances/situations/stages where the student felt they had been 'talking to learn'. These responses were then used to frame their own autobiographies to highlight their own first and second language learning experiences. 
Running through this module was the notion of planning for effective exploratory talk and classroom dialogue. There were some very explicit opportunities created for modelling the planning and teaching of talk and dialogue for the students; for example, ranking reasons to support effective exploratory talk in a ground rules exercise. (Scott and Coultas, 2014). These materials build on the work of the National Oracy Project (NOP), Norman (1992) and Mercer (2000). This task encouraged students to think about how groups functioned well. The discussion also focussed attention on the need to choose a topic that would engage the group and to create a task that required the students to think together to solve a problem or rearrange information, what is called 'real group work' (Coultas, 2007). Stuart Scott, from the Collaborative Learning Project (Scott, 2011) also introduced the students to his website and taught them how to create resources that would require students to talk and work collaboratively.

The students then worked collaboratively, in pairs, to create their own lesson based on a talk task. Florence's lesson was a simulation based on booking a trip abroad with a set amount of money. Students in the seminar had to reach a consensus about their choices for the trip using exploratory talk and discussion. The group process took place over a sustained period of about 20 minutes. The topic was a strong choice and engaged the group and the structure imposed, by having a set amount of money, forced participants to make clear choices. Some of the prepared prompts to promote discussion were not used as they focused on more formal persuasive language and the task particularly required students to give reasons for their choices in a more informal context. So, while the task worked well, perhaps the distinction between exploratory talk and presentational talk (Barnes, 2008) needed to be interrogated further to understand the appropriate register to use in different contexts.

\section{The pedagogy of the Educational Technologies Module}

This module was designed to explore how technology-based educational resources can be used to facilitate second language learning. Originally, the module focussed on commercially available materials e.g. DVDs for language teaching which did not encourage much critical discussion. In a new approach, an authentic learning and teaching environment was chosen so that a real audience would shape the novice teachers' understanding of the challenges and possibilities of using educational technologies in a distance learning context. The master's students designed and put online language teaching materials for authentic language learners based in France (Lyon) also on a master's course to become primary school teachers.

Brown, Collins, Duguid (1989) argue that knowledge can be thought of as tools. It is possible to acquire knowledge. Language which is context dependent (I, you, here, now, that) people can interpret face to face because they have access to the situation. When the context is absent e.g. over the telephone this language becomes ambiguous (Brown, Collins, Drguid, 33-36).

The students were therefore scaffolded in an authentic situation in which they were given workshops on distance learning, educational technologies, language tasks, and peer and tutor 
feedback on tasks they created to facilitate language learning through the university virtual learning environment (VLE).

\section{Task-based learning and teaching materials and on line language learning}

The online assignment used an activity-based learning approach in which the students created their own language tasks. As explained earlier such tasks can be described as those where meaning is primary, there is a goal that needs to be worked towards, the outcome of the activity is evaluated and there is some sort of comparability to real world activities: the language learning is therefore the by-product of the tasks (Skehan 1998, 268).

Students were also introduced to the concept of distance learning and what that means for language acquisition. The students created their own tasks and presented these tasks to their peers and the lecturers. This gave them the opportunity to receive peer feedback and evaluation. Some students clearly understood what topics, skills and language would be relevant to their French counterparts, whilst for others there was a lack of awareness of the language level and relevance of tasks. For example, one student had childish cartoons to help teach vocabulary which would have patronised the Lyon-based students and therefore she had to adapt these materials and think more carefully about the audience.

\section{Material for the case study}

Florence was a student on the one year master's programme. His first language was Italian with English as a second language and some understanding of German. He had only recently moved to the UK as a student on this master's programme. He had some experience in teaching English as foreign language but was essentially a novice teacher. The Oracy and ELT Pedagogy module was studied at the beginning of the programme and the Educational Technologies for English Language Teaching module in the second semester.

Narrative enquiry, and in this instance the case study approach, was chosen as Pinnegar and Danes (2007) suggest because narrative is able to: 'embrace the power of the particular for understanding experience’ (p.24). The Talk Autobiography formed the stimulus for the narrative enquiry and allowed for critical reflection by the student as he looked back and retold his story from the particular viewpoint of an older self .This self-evaluative approach as Miller (1995) suggests, allows for more reflexivity as it shows students openly 'where [they are] coming from' and 'what [their] strengths and weaknesses are as [commentators]' (Miller, ibid, p.26). Coffey (2001) suggests that auto ethnography has become a more familiar feature of contemporary research making 'it is easier to utilize genres such as the auto/biographical and the personal narrative/confessional' (p. 10). But, in particular, the Talk Autobiography allowed students to create meaning through telling a story and reconsidering key moments in their lives to make sense of their own experiences (Britton 1970; Rosen 1985).

Therefore the material from which the case study is drawn includes: 
Florence's talk autobiography which was his narrative account of his language learning in a first and a second language and his evaluation of the role of talk in learning ${ }^{\mathrm{i}}$

The rationale for the online language learning tasks for his students in France and the written evaluations of the French students ${ }^{\text {ii }}$;

The weekly diary as he prepared his language learning task in the second module ${ }^{\mathrm{iii}}$;

Florence's reflections on how the Oracy module fed into the Educational Technologies module ${ }^{\mathrm{iv}}$.

We aimed to use the student's reflections to allow the student's voice to express itself in this article. We then used 'the constant comparative method' (Thomas, 2009, 198) to look for similarities and differences within the data to identify some key themes. Cooper and McIntyre (1983) describe this approach to the analysis of qualitative data as empirical phenomenology, where the researcher continually refines and tests the themes as they unfold.

\section{Themes drawn from the study}

We now return to the questions posed in the opening of this article and evaluate the students learning according to those three categories. As stated above, we draw closely from the student's reflections and writing as our evidence base.

\section{Role of narrative and personal experience in language learning}

Using a narrative approach, modelled by both lecturers through talk and writing, Florence opens his Talk Autobiography with an account of an embarrassing moment using his native language Italian when four years old:

I was in the middle of a football field, at the end of a friendly tournament...I was granted the opportunity to ask a question of a famous footballer...A microphone that was obviously too big and heavy for my hands was given to me, and I clearly recall me shouting all of a sudden "Ti voglio tanto bene! [I love you so much!]...Too embarrassed to continue, I dropped the mike, burst into tears and ran to my mum. (Talk Autobiography)

Florence has utilised the structure of one of the lecturer's narrative accounts of their language learning and an amusing moment to help record and give meaning to events in his own life. This expressive mode allowed each student to revisit their own feelings and experiences about chosen moments in their lives and produced some powerful talk and writing.

\section{What prior knowledge and experience had Florence brought to his learning?}

Sporting activities, such as skiing, and other interactions with peers allowed the teenage Florence to begin to communicate more effectively in English. Florence's enthusiasm to explore English was sparked by an authentic engagement with both language and the arts as well as through interaction with peers. In the language autobiography, Florence shows that 
home literacy practices and oral literacy events (Brice-Heath, 1982) were a rich source of learning from a young age:

I remember with great joy particularly a special ritual that I shared with my mother during the evenings, during my childhood years. Both of us were very passionate about drama and reading and we would enact entire scenes and chapters of our favourite stories and novels. (Talk Autobiography)

Talk and reading were both nurtured in this family's life. Storytelling opportunities are mentioned as are the re-enactment and discussion of literature and stories with his parents.

However, some of his language learning experiences as a teenager were mixed. He learnt English in school in a very formal manner with not much role play or discussion and a focus on language accuracy. In his Talk Autobiography he highlights feelings of frustration and his own inadequacy which may well have contributed to Florence's implicit idea that teaching could be different.

I remember ..., very distinctly, how frustrated children can feel when they see their opinion always undervalued and underestimated. (Talk Autobiography)

Through the first module we gained an explicit understanding of his language learning and social and educational background. Roberts $(1998,154)$ explains that in order for studentteachers to be critical of the input presented to them, they need to reflect on the prior knowledge that they bring to professional education. Goodson (2003) also emphasises the importance of life history work in teacher education for stimulating critical reflection.

Through his own experience with language use in student groups and his reflections on his home and peer literacy practices, he began to realise that language learning is collaborative, that meaning through language is negotiated, discussed and scaffolded. In his evaluation of the on line learning workshop task he shows how he has internalised these ideas in his teaching. This knowledge became apparent in the way that he tried build up rapport and set up a task with his French students that not just invited but required interaction in the second module. This was so that students could feel at ease with him as a teacher and for them to have to interact with him and each other.

I tried to structure my workshop by following the school of thought of sociocultural theory....as a process of participation, negotiation and mediation of knowledge... with peers and the teacher.

Early memories he had when trying to communicate in L2 English were marred by the fact he felt inadequate. So he knew that building a rapport was vital. In fact the research into student anxiety supports this notion that speaking in L2 raises anxiety levels more than any other type of activity (Hurd 2007). But he had also planned carefully for peer and teacher interactions.

\section{In what way has he transferred knowledge from one module to another?}


When students start designing the tasks to go online they often bring with them ideas on how they learnt languages and so can be conservative in their tasks and topics. This is understandable and it is the starting point for them to develop more engaging tasks. Florence was no different in that his thinking was shaped by his previous experience. What was different was that he had developed a high level of critical insight into his own language learning experiences in the Oracy module and this clearly focused his teaching on facilitating language and meaning rather than simply the transmission of knowledge.

He brought a 'sociocultural' approach to language teaching which he applied to his language learning tasks. His language learning tasks centred on what practicing teachers have to cope with on a day-to-day basis in a classroom. Florence's tasks built upon the hopes, wishes and fears of primary schools teachers in the French education system. As he stated in his weekly diary, 'these tasks were designed to enable and reshape old knowledge', a quotation from Barnes (2008) whose work was studied in the Oracy module. Similarly his reflections on giving learners freedom to express themselves in order to accomplish a very specific task derived from what he had learnt in the Oracy module.

Florence's reflected on how stressful producing spontaneous language can be when buying groceries in a foreign country in his Talk Autobiography: He states that on a summer study abroad programme in Bournemouth:

I remember how I experienced ....the pressure of having to constantly rely on a skill set that is different from your own. When for the first time I had to buy some groceries, I realized that my language was... way too formal and strict, because I had never experienced these kinds of 'everyday events’. (Talk Autobiography)

This was taken into account in the second module by giving learners the scaffolding, for example by introducing himself on Skype, so that they could express personal ideas within a supportive framework of the expectations and reality of teaching. Hence the importance of teacher modelling and scaffolding work on spoken language as discussed in detail in the Oracy module and the work of the NOP, Norman (1992).

The Talk Autobiography highlighted his feelings of inadequacy when speaking to his Czech friends 'who were just too good and advanced for my level'. As a consequence he decided, during the Skype interactions with his French students, to focus only on language previously met and on pronunciation errors that inhibit meaning and understanding. In fact, according to the weekly diary entry, his students enjoyed the interaction because they did not have much opportunity for such genuine everyday interactions back home in France.

\section{What has he learnt about ELT pedagogy?}

Florence faced some problems in the design and execution of the online language learning tasks. One of the teaching strategies he learnt was how to adapt his way of giving feedback to the online learners. His feedback to students' discourse was to negotiate meaning (Pica 
1988). As one Lyon student explained in the feedback to Florence: ' ... the teacher was benevolent, helpful and careful of my work and answers: correction, explanation...'

What this student seems to appreciate is clarification of meaning rather than always receiving explicit feedback on language errors. In this way Florence learnt how to facilitate language learning in a more positive environment because he understood that second language learners need to notice the second language (Schmidt 1990) and clarify meaning to restructure (McLaughlin 1990) their language. He understood the importance of social interaction and how the task design can affect interaction patterns. So instead of initiation, response, feedback (IRF) type interaction, he encouraged more open ended expressive discussion and exploratory talk, through encouraging learners to express their hopes and fears.

He was also aware that some learners may have doubted the design of open-ended tasks, where there is no 'correct answer,' as this could leave students thinking that the tasks are not rigorous enough. This is indeed a challenge for many teachers when faced with students expecting more traditional language learning tasks (Coultas, 2007, 2012). The answer may lie in choosing topics that the group or the individual learner can relate to and plan tasks that involve problem solving (Coultas, 2007). Moreover, collaborative tasks should also encourage learners to reflect and check their use of language in order to keep them interested (Richards, 1994). The more informal language exchanges encouraged throughout these modules contrasted with the formality of learning English in school. There is evidence of critical engagement with his home and school learning practices as he questions the overdependence on formal grammar and writing exercises and silent classrooms.

I remember these very old-fashioned teachers... conducting entire lessons where children were not allowed to talk and where the focus of every activity was on grammar and on these monotonous writing drills concentrated on a good calligraphy. I remember how frustrated children can feel when they see their opinion always undervalued and underestimated. (Talk Autobiography)

While he is critical of the lack of use of talk to articulate thinking in the classroom, he also explains that some of the discipline of the grammar lessons may have had a positive impact on him as a language user.

In retrospect, this kind of approach helped me understand how having control of a well-designed, grammatical set of language skills can immediately influence the impression on you make to your interlocutor of yourself and of your educational status. (Talk Autobiography)

Freedom to express one's views can be difficult for learners who come from a traditional learning environment where the focus tends to be on the product rather than the process of language learning (Boulton, Chateau, Pereiro and Azzam-Hannachi 2008). The building of students' confidence in speaking English as a second language may be in sharp contrast to their experiences in their usual 'getting it right' language learning classes. But his feedback from one of the online students explained they were interested in using 'everyday' English rather than 'school English'. 
To me, working with an Englishman is very helpful because when I had a question, I asked my teacher which gave me how English persons talk 'everyday'. It's not 'school English' but a language used in the true life.

This explains why we need to give students experiences of a variety of purposeful spoken language use. What they may have experienced in Florence's approach was authentic communication, 'language used in the true life', rather than the more teacher-directed language production to display language knowledge.

Understanding students' perceptions made Florence aware that distance learning places an even greater importance on explanation. He found that the nature of distance learning means that explanation of the aims of the tasks was key (Boulton and Booth 2001). He was aware that some of the tasks may not have been what his learners were used to and so understood why justifying the tasks in terms of language learning was crucial in this context.

Furthermore, how tasks are explained to students was also mentioned as being important as distance learning makes it impossible to give further explanations when something is unclear. Being very specific (Canter, 1992) or modelling what you are asking the students to do is always a feature of good teaching in any context.

\section{Reflections of the student on the connections between the two modules}

Florence's reflections on the overlap between the modules and how they complimented each other were grouped into major themes. He was also asked about the support he received during the modules, and any progress he felt he had made as a result of attending both modules.

1. Interactional model: One of the themes highlighted was that both modules emphasised the need to go beyond the Initiation+Response+Feedback (IRF) in teaching moves and use open ended questions and tasks. Florence was aware of a weakness in this type of interaction in that engagement is often lacking in teacher-student discourse. He began to understand that using only closed questions or tasks does not help learners to engage with knowledge: thus clarifying their thinking and language use to enable them to sustain conversation and elaborate in a second language required going beyond the IRF.

Both modules have emphasised the importance of overcoming the traditional 'Initiation + Response + Feedback' (IRF) teaching moves, in order to enhance learners' level of engagement. (Personal communication, 8 February 2016).

2. Nature of task/Problem solving: Florence highlighted the use of problem-solving to encourage collaborative talk. Both lecturers used a problem-solving approach in their teaching which encourages functioning knowledge i.e. knowledge which can be applied (Biggs and Tang 2011). One of the goals of both modules was for beginning teachers of ESL to plan and rehearse collaborative problem solving tasks in different contexts. Florence states:

Whereas the Oracy module favoured students' collaborative type of talk through the use of different tasks (such as paired problem solving, jigsaw groups and thinking sheets), the Educational Technologies module encouraged the use of technology in 
order to mediate student-teacher collaboration, for instance through e-mail/social media/Skype interaction. (Personal communication, 8 February 2016).

He also adds:

The Ed. Tech. module has also given me the opportunity to adjust to an online context some of the tasks proposed during the course of the Oracy module. (Personal communication, 8 February 2016).

This shows that information and skills provided in one module were linked to the other. Firstly, it made Florence aware of the need to put collaborative talk into practice, rehearsing in front of students in the first module working in pairs and then preparing a task for French students on his own in the second module. Secondly, it provided him with the opportunity to apply planning for student interaction in real-life settings.

3. Authentic learning: Authenticity was also a key factor in the design of his online language learning tasks (Waring and Evans 2015). Florence chose topics in both modules which motivated learners to produce meaningful language. The Oracy module had encouraged personal expression through the narrative of a Talk Autobiography as way of understanding how language is purposeful and a product of social and community interactions and therefore variable and context dependent. Florence suggested:

Both modules have also underlined the fundamental role of authenticity of a task: real and authentic purposes have indeed an important role in making the task engaging and at the same time relevant. (Personal communication, 8 February 2016).

Florence therefore understood that teachers need to create meaningful, authentic and purposeful contexts for students to engage with talk tasks in classrooms. (Coultas, 2007)

4. Support and scaffolding: in which students are provided with sufficient challenge so that they can achieve their goals (Waring and Evans 2015). The Oracy module encouraged reflection on his previous language learning experiences as well as planning his own language tasks with his peers. Florence believed this fostered empathy with language learners. He understood the importance of social bonding and cohesion and scaffolding by the teacher or more knowledgeable other, which was reflected in the feedback from the French students:

This course has allowed me to plan, with my teachers' support and through suggestions among classmates, three tasks that aimed to both engage with learners' interests and passions and improve some of the linguistic weaknesses, which had been previously highlighted by the learners themselves in the e-mail interaction. (Personal communication, 8 February 2016). 
5. Learner-teacher relationship: Both modules, Florence thought, encouraged an increased awareness of the importance of collaboration between teachers and students. This may have been in sharp contrast to some of his experience in teacher-centred classrooms in which the teacher is seen as the fountain of knowledge. This chimes well with a task-based approach in which language is the by-product of task completion and exploratory talk in which meaning is constructed through oral interaction.

They also made me confident in the fact that the figure of the teacher does not necessarily have to be seen as the one of 'dispenser of knowledge', but can also represent the role of the facilitator, in a classroom where learning does not always come from the 'top' but, in a certain sense, is 'shared from the bottom. (Personal communication, 8 February 2016).

Florence clearly understood that it is not only the lecturer but the learners that help to construct knowledge if opportunities are created for this.

\section{Discussion}

Waring and Evans $(2015,59)$ highlight that discussion with learners about their previous affective and motivational aspects of learning can help them consider the impact of their attitudes towards learning and their motivations towards teaching contexts. The critical reflections in his Talk Autobiography allowed Florence to revisit his experiences of language learning and open up new avenues of thought about teaching.

The lecturers based their approach to teaching through particular tasks and the students were given time to ask questions, assimilate, and eventually use the different strategies to promote 'talk for learning' within their own groups. However on the MA the students were encouraged to read around these approaches and delve into the philosophy and ideas of the social construction of knowledge that underpinned them. The Oracy module also aimed to make the students feel comfortable in the university setting through encouraging a bonding process between lecturer and students based on shared and humorous personal narratives of language learning experiences.

Florence underlines these sociocultural processes of learning when he says that learning is 'a process of participation, negotiation and mediation of knowledge by the learner together with peers and teachers'. He suggests that this approach can be called 'collaborative learning'. He has assimilated the idea of the teacher as a facilitator of learning breaking with didactic traditions to plan for meaningful interactions in an ESL face to face and online learning context. But there is also an understanding of the importance of the personal and expressive modes of language underlying some of his thinking and choice of task. For example, he suggests in this second module evaluation that learners need to 'generate personal and original products' in justification of his YouTube video introducing himself to the students and getting them to reciprocate. He also explains his motivation for this as 'encouraging learners' individualities' so that they become active participants in language learning. 
In his evaluation Florence is very pleased with the feedback of the French students who appreciated the authenticity of his task: they have appreciated the helpful nature of Florence's facilitation of the tasks and welcomed the topic and design of the tasks i.e. the expectations and realities of being a teacher. The multi-modal nature of the tasks also helped to stimulate his students' interest in learning. But he also suggests that he would favour more peer to peer interaction around the task through the use of WhatsApp as they engage with the task 'where learners would feel more comfortable expressing their own opinions'.

Throughout his experience of the Oracy and Educational Technologies modules, Florence showed a sophisticated approach to learning. Evans describes this approach as related to abstracting meaning and interpreting information to understand the world (Evans 2014, 189). Florence's talk autobiography highlights how he constantly sought ways of engaging with his peers and target language to develop his second language. Through the online language tasks he engineered negotiation of meaning through interaction with his French, English language learners so that they would complexify their use of English.

Florence appreciated the value of coping with not knowing. His own experience of putting himself in situations where the language is unexpected, complex and new is mirrored in the topic and tasks he set to reflect on the challenges of teaching which resonated with the students and allowed them to stretch their second language.

\section{Planning and rehearsal to embed collaborative work}

A key finding of this case study is that the focus on 'exploratory talk' in the first module complemented and prepared the students for the 'task-based learning' approach in a different context in the second module. The idea of exploratory talk, or as Barnes (1976) first coined it 'the classroom conversation', focuses on the social construction of knowledge through students articulating their inner voices to each other in the security of the small group before moving to presentational talk to a larger group. Task-based learning, in the English as a foreign language tradition, highlights the notion that meaning is primary, that the task has to be comparable to a real world situation, that goals have to be clear and that the outcome of the task needs to be evaluated.

The teacher's role changes in both contexts as they need to step back and plan carefully for a more independent form of language learning. To create a purposeful independent language learning environment requires real understanding of how humans acquire and develop language and the ability to rehearse and plan for effective and authentic interactions by choosing topics and tasks that resonate with students (Coultas, 2007). This is best undertaken in a collaborative context especially for beginning teachers.

\section{How this work might go further}

Florence clearly got a lot out of these modules. For the Educational Technologies module he was able to reflect on both his and his students' learning experience. The approach to online language learning was through task-based instruction, an approach well suited to distance learning. But what some students ignored was to reflect on whether a task-based approach is 
indeed optimal for the learners in France. The tasks are designed to foster accuracy, complexity and fluency (Skehan and Foster 2001). The question is whether this type of approach to language learning and teaching is appropriate in this type of context. MA students rarely question this approach. Would a chat room type of forum be more appropriate? Florence is beginning to consider this in his suggestion of using a more interactive form of communication WhatsApp for example that could facilitate more 'exploratory talk’ on line.

\section{Conclusions}

Gibbons (2009) suggests that an effective curriculum for EFL learners should be a 'Janus Curriculum' which faces in two ways, where 'prior learning and the everyday language.......provide a bridge to new learning' (p. 59). She also argues for tasks that have high challenge and high levels of support built into them. We can see this approach informing the thinking behind these two modules in specific ways.

\section{Personal experience, talk and narrative}

By telling the story of his early experiences of talk, Florence developed critical insight into his previous language learning experiences which prepared him to review his values and beliefs as a beginning teacher. In his evaluation of his Talk Autobiography, Florence asserts that the connections between his language learning and his social and cultural experiences in the home and among his peers 'could have just remained unnoticed forever. For instance the routine of the entire scenes of a novel recited together with my mother which built enthusiasm and passion for novels and drama' but by writing his language autobiography and reviewing his life history he understood the need for a teacher to change their role and become 'a learning facilitator and enabler and not only a figure that conveys knowledge'.

\section{Planning for authentic and meaningful interactions}

He was also able to apply these insights in creative ways to planning effective teaching tasks in both modules. By looking closely at his planning and evaluative essays he gives a rationale for the tasks set that, as Gibbons (ibid) suggests, both challenged and supported learners in his MA group and in France to use a more authentic and independent level of language. He highlights the importance of being able to set up 'challenges for students that will allow them to reshape old knowledge' in his evaluation of his Talk Autobiography through exploratory talk and talk based tasks. The implication for ELT education is that novice teachers need to understand the perspectives of their own students but this can be achieved through critical reflection and is not necessarily done through a needs analysis.

\section{A changing role for the teacher}

Florence also shows some awareness in both modules that the teacher adopting a different role and promoting a more independent learning context will 'not always be appreciated by students' who are unfamiliar with this kind of pedagogy (Coultas, 2012). This emphasizes that students teachers therefore need to be inducted into this approach and supported in the 
planning, rehearsal and evaluation of effective open-ended group tasks to be able to engage critically with dominant transmission modes of teaching, (Coultas, 2007).

\section{The power of collaborative teaching and learning}

The collaboration and team teaching between lecturers and students during the modules, the sharing and close study of the lecturer and student Talk Autobiographies and the evaluation after the modules demonstrate how powerful a process the 'horizontal' sharing of good practice through narrative reflections and a case study can be.

As Rosen suggests the project of reaffirming the centrality of talk and narrative ' involves not only reconceptualising the school curriculum from the point of view of its narrative possibilities' but also 'as a medium for teachers to continually review the values and beliefs that shape their everyday practice' $(1985,19)$. He suggests that such as approach allows us to think not just about what we can do but what we might be able to do.

\section{Acknowledgements}

We are thankful to Laura Timms, Keith Grieves and the editorial members and reviewers who helped us in the drafting of this article. 


\section{References}

Alexander, R.J. 2004. Towards Dialogic Teaching: Rethinking Classroom Talk Cambridge: Dialogus.

Alexander, R.J. 2008. "Culture, Dialogue and Learning" in Mercer, N and Hodgkinson, S (Eds) Exploring Talk in School London: Sage, 91-115.

Barnes, D. 1976. From Communication to Curriculum. Harmondsworth: Penguin.

Barnes, D. 2008. "Exploratory Talk for Learning" in Exploratory Talk in School, edited by N. Mercer and E. Hodkinson, 1-17 London: Sage.

Biggs, J. and Tang, C. 2011. Teaching for quality learning at university. $4^{\text {th }}$ ed. Open University Press: Berkshire.

Boulton, A. Chateau, A. Pereiro, M. and Azzam-Hannachi, R. 2008. Learning to learn languages with ICT - but how? CALL-EJ Online, 9/2. Retrieved from:

http://www.tell.is.ritsumei.ac.jp/callejonline/journal/9-2/boulton.html

Boulton, A.and Booth, P. 2001. Communication in the void and communication avoided: A case-study of on-line language teaching. ASp, 31-33, 89-102.

Brice Heath, S 1982. Ways with Words: Language, Life and Work in Communities and Classrooms Cambridge: Cambridge University Press.

Britton, J. 1970. Language and Learning. Harmondsworth: Penguin.

Brown, J. S. Collins, A. \& Duguid, P. 1989. Situated cognition and the culture of learning. Educational Researcher, 18 (1): 32-42.

Brutt-Griffler, J. and Collins, J. 2007. "English as a multilingual subject: theoretical and research perspectives.” In Rethinking English in schools: towards a new and constructive stage, edited by Viv Ellis, Carol Fox, and Brian Street, 158-173. London and New York: Continuum.

Canter, L. 1992. Lee Canter's Assertive Discipline Elementary Workbook. Santa Monica, California: Lee Canter and Associates, Inc.

Clandinin, J. and Connelly, M. 2000. Narrative Inquiry Experience and Story in Qualitative Research. San Francisco: Jossey-Bass.

Coffey, A. 2001. Education and Social Change Maidenhead: Open University Press.

Cooper, P. and McIntyre, D. 1983. "Commonality in teachers' and pupils' perceptions of effective classroom learning." British Journal of Educational Psychology, 63, 381-399, Milton Keynes: Open University Press.

Corden, R. 2000. Literacy and Learning through Talk Strategies for the Primary Classroom Milton Keynes: Open University Press.

Coultas, V. 2007. Constructive Talk in Challenging Classrooms Oxon: Routledge.

Coultas, V. 2009. 'A Life in Collaborative Learning: an interview with Stuart Scott, the Director of the Collaborative Learning Project about his influential work in developing 
effective talk and group work in multicultural classrooms' (Interview) English Drama Media (February) pp 43-48.

Coultas, V (2012) Classroom Talk: Are we listening to Teachers’ Voices? English in Education 46 (2 summer): 175-190.

Coultas, V. 2015a. Teachers' narratives of classroom talk: what are the challenges? Unpublished $\mathrm{PhD}$ Thesis, UCL Institute of Education.

Coultas, V. 2015b. Revisiting Debates on Oracy: Classroom Talk-moving towards a democratic pedagogy? Changing English: Studies in Culture and Education Volume 22, (1): 72-78 http://www.tandfonline.com/eprint/TVth2HX4yTKEhDpusvMP/full accessed 2nd May 2015

Coultas, V. 2015c. Stephen Eyers: talking about talk: a life in speaking and listening. Teaching English, NATE 7: 62-65. ISSN (print) 2051-7971.

Coultas, V. 2018. Autobiography, Talk and the power of the personal in the teaching of English English in Education 52 (2) 1-13.

Evans, C. 2014. "Exploring the use of a deep approach to learning with students in the process of learning to teach." In Learning patterns in higher education: Dimensions and research perspectives, eds. D. Gijbels, V. Donche, J. T. E Richardson, and , J. D. Vermunt, 187-213. London: Routledge.

Eyers, S. and Richmond, J. 1982. "Talk Workshop Group: An Introductory Paper." Talk Workshop Group 1982 Becoming Our Own Experts The Vauxhall Papers London: ILEA English Centre.

Eyers, S. 2015. Collaborative Teaching for Collaborative Learning Unpublished paper for Communications, Language and Literacies Special Interest Group, School of Education, Kingston University, May 31 2015.

Gibbons, P. 2009. English Learners Academic Literacy and Thinking-Learning in the Challenge Zone, 118-130. New Hampshire USA: Heinemann.

Goodson, I. 2003. Professional Knowledge, Professional Lives, Maidenhead: Open University Press.

Holbrook, D. 1979. English for Meaning. Windsor: NFER.

Hurd, S. 2007. "Anxiety and non-anxiety in a distance language learning environment: The distance factor as a modifying influence." System 35: 487-508.

Long, M. H. 1996. The role of the linguistic environment in second language acquisition. In Handbook of Second Language Acquisition, eds. W. Richie and T. Bhatia, 413-468 Academic Press: San Diego.

McLaughlin, B. 1990. "Restructuring."Applied Linguistics, 11 (2): 113-128.

Mercer, N. 2000. Words and Minds. London: Routledge.

Mercer, N and Hodgkinson, S. eds. 2008. Exploring Talk in School London: Sage.

Norman, K. 1992. Thinking Voices- The Work of the National Oracy Project London: Hodder and Stoughton. 
Miller, J 1995. 'Trick or Treat? The Autobiography of the Question’ English Quarterly 27 (Spring): 22-26.

Pica, T. 1988. "Interlanguage adjustments as an outcome of NS-NNS negotiated interaction." Language Learning 38: 45-73.

Pinnegar, S and Daynes, J, G (2007) Locating Narrative Enquiry Historically: Thematics in the turn to Narrative in Clandinen (Ed) Handbook of Narrative Enquiry: Mapping a Methodology pp 3-34 London: Sage Publications.

Prabhu, N. S. (1987) Second language pedagogy. Oxford: Oxford University Press.

Richmond (2015) Talk UKLA Owen Education .

Richards, K. 1994. "Writing distance learning materials." In English language teaching and distance learning, edited by K. Richards and P. Roe, 94-107. London: MacMillan.

Roberts, J. 1998. Language teacher education. London: Arnold.

Rosen, H. 1985. Stories and Meanings, Sheffield, UK: NATE

Rosen, H. 1996. Autobiographical Memory, Changing English, 3:1 21-34. doi: 10.1080/1358684960030103.

Schmidt, R. 1990. "The role of consciousness in second language learning." Applied Linguistics, 11: 129-158.

Scott, S. 2011. Collaborative Learning Project available at http://www.collaborativelearning.org Accessed on 28 ${ }^{\text {th }}$ November 2011.

Scott, S and Coultas, V. 2013. Ground Rules Diamond Nine Collaborative Learning project available at http://www.collaborativelearning.org Accessed on January $3^{\text {rd }} 2013$

Skehan, P. 1998. "Task-based instruction." Annual Review of Applied Linguistics, 18: 268286.

Skehan, P. and Foster, P. 2001. "Cognition and tasks." In Cognition and in second language acquisition, edited by P. Robinson. Cambridge: Cambridge University Press.

Thomas, G. 2009. How to do your Research Project. London: Sage Publications.

Vygotsky, L.S. 1986. Thought and Language. Cambridge MA: MIT Press.

Waring, M. and Evans, C. 2015. Understanding pedagogy: developing a critical approach to teaching and learning. London: Routledge.

Wells, G. 1987. The Meaning Makers. London: Hodder and Stoughton. 


\section{Appendix 1: Talking to learn autobiography graph (Secondary National Strategy)}

[Insert Figure 1 here]

This sheet was used to identify the stages in the student's life where they felt they were using talk to learn. 


\section{Appendix 2: Questionnaire to Lyon based students}

The questionnaire below was sent to the master's students in France who completed the tasks which the UK based students on the MA ELT created to inform their written evaluations of the experience.

Pourriez-vous évaluer les matériaux en ligne et répondre aux questions suivantes :

[Can you evaluate the online materials and respond to the following questions:]

1. L’atelier a-t-il atteint les objectifs pédagogiques? Expliquez votre réponse.

[Does the workshop achieve the stated learning objectives?]

2. L’atelier a-t-il facilité l’apprentissage de la langue anglaise? Expliquez votre réponse. [Does the workshop facilitate English language acquisition?]

3. Les matériaux multimédia sont-ils utilisés efficacement pour aider à améliorer et consolider l'apprentissage de la langue? Expliquez votre réponse.

[Do the multi-media materials make appropriate and effective use of multimedia to support and enhance learning?]

4. Comment les matériaux engagent-ils l'apprenant?
a. tâche 1
b. tâche 2
c. tâche 3

[How do the materials engage the learner?]

5. Expliquez comment les matériaux facilitent l'apprentissage dans un contexte électronique à distance?

[Explain to what extent the materials facilitate online language learning?] 
Notes

${ }^{\text {i }}$ Reflection on the Oracy module was taken from his written assignment for this module (Talk Autobiography).

ii Reflection on the Educational Technologies for English Language Teaching was taken from his written assignment for this module.

iii This diary was accessed via the university's VLE.

${ }^{\text {iv }}$ Personal communication (email).

\section{Notes on contributors}

Valerie Coultas is a writer and educational researcher and author of Constructive Talk in Challenging Classrooms, Routledge (2007). She worked as an English teacher in London Schools for over two decades before becoming a teacher educator/researcher. Her research interests include oracy, gender and English and education and social justice.

Paul Booth is Senior Lecturer at Kingston University, London. His research interests include second language vocabulary, especially individual differences, lexical diversity and frequency. He has also researched situated learning and language teacher development and runs a graduate course in Applied Linguistics for TESOL. 